\title{
Work Force Retention: Role of Work Environment, Organization Commitment, Supervisor Support and Training \& Development in Ceramic Sanitary Ware Industries in India
}

\author{
${\text { Umamaheswari } S^{1} \text { iD, Jayasree Krishnan }}^{2}$ \\ ${ }^{1}$ Sathyabama University (India) \\ ${ }^{2}$ St. Joseph's College of Engineering (India) \\ umaaishwarya99@gmail.com,jayasree.krishnan@gmail.com
}

Received: January 2016

Accepted: June 2016

\section{Abstract:}

Purpose: Although retention of employees has become hot topic in this career turbulent era, practically no empirical research is carried out in the fast growing ceramic sector till now and this research fills the gap in the literature. The literatures surveys reported that organization commitment is an important determinant of retention and work environment, supervisor support and training and development are the most relevant antecedents increasing commitment towards organization. This paper examines the impact of the above factors over organization commitment and explores the effects of organization commitment on retention, and verifies the mediating effect of organization commitment on the relationship between proposed factors and retention.

Design/methodology/approach: A survey was completed by 416 employees working in five ceramic sanitary ware factories located at different places in India. Questionnaire consisting of items adopted from previous researches were used to collect data. The selection of respondents was based on the simple random sampling.

Findings: Findings reveals that organization commitment influences retention and all the above factors enhances it. Moreover organization commitment partially mediates the relationship between proposed factors and retention. However multiple regression analysis indicated that training and development did not have any notable influence on retention. 
Research limitations/implications: This study was conducted in a particular country and also in a particular sector of manufacturing industry, which limits generalization. Possibility of bias towards their organization and assumption that respondents know about their organization are other limitations.

Practical implications: This paper offers recommendations to HR (Human resource) managers that they should extend their support to work environment, supervisor support and training and development in order to generate better relationship with employees and to reduce their likelihood of leaving the company.

Originality/value: This article makes significant contribution to most turnover prone Indian environment, highlighting the important factors to be given priority for employee's retention.

Keywords: work environment, supervisor support, training and development, organization commitment, employee retention

\section{Introduction}

The fierce competition globally for skilled employees has made it pertinent for manufacturing industries to exert more attention upon retention of skilled workforce. However talent, an intangible asset and managing talented employees create a number of challenges and retention process become more exigent, especially with this new generation of workforce exceptionally mobile and always looking for better opportunities (Bogdanowicz \& Bailey, 2002; Correia de Sousa \& van Dierendonck, 2010). Employee turnover rates over next five years is predicted to rise to $23.4 \%$ and the number of global departures in 2018 is expected to be 192 million (Biswas, 2013). Further surveys predicted that highest turnover rate of $26 \%$ in India (Hay Group, 2013) placing India in the eye of employee turnover storm. The data base of Docquier and Rapoport (2009) reveals that more than one million skilled Indian emigrants worldwide in 2000, placing India second just to the Philippines among developing countries for the number of skilled emigrants living in the organization for economic cooperative and development (OPED) countries such as Australia, USA and the UK. Also bulk number of $\mathrm{H}_{1}-\mathrm{B}$ visa holders $(1,54,726)$ in the USA, a visa aimed at skilled category in the year 2008 reveals the large number of skilled professionals migration aiming greener pastures. This plight of skilled workforce affects Indian organizations alarmingly. The loss of skilled workers not only slow down the success of "make in India" scheme, but also will make the quest of achieving India's vision to become a developed nation in the year 2020, a challenging task. Moreover the world of business community swirls towards skilled workers as their talents are highly 
valuable for their successful business operations, which can create the possibilities of employee's poaching and in coming years the companies will go to "war for talent" (Beechler \& Woodward, 2009). The best insurance against attrition is not to hope for lack of opportunities outside, but to build strong internal conditions which act like a glue to employees (Biswas, 2013) and organization in India must give serious thought to what drives employee's commitment (Sinha, 2013).

A large number of researches were attempted to answer the question what determines employees intention to quit by investigating possible antecedents of employee's intention to quit, (Kramer, Callister \& Turban, 1995; Saks, 1996; Kalliath \& Beck, 2001) and the researches supported that lack of commitment is the most immediate determinant of intention to quit (Igbaria, Meredith \& Smith, 1994; Firth, Mellor, Moore \& Loquet, 2004; Parasuraman, 1982) and commitment to organization can significantly reduce the intention to quit (Somers, 1995; Meyer, Stanley, Herscovitch \& Topolnytsky, 2002; Paré \& Tremblay, 2007; Bagraim, 2010).

Commitment is a multi-foci concept and an employee can be committed to his/her job, supervisor, peer, or organization (Boshoff, 2000; Morin, Morizot, Boudrias \& Madore, 2010; Paillé, Fournier \& Lamontagne, 2011) Also a large body of researches confirmed the positive relationship of organization commitment to retention (Steers, 1977; Jaros, 1997; Carmeli \& Weisberg, 2006; Neininger, Lehmann-Willenbrock, Kauffeld \& Henschel, 2010; Firth et al., 2004; Ingram \& Lee, 1990). Hence it would be argued that, if employee's organization commitment level is highly significant, probability of their continuation will be high. Organization now-a-days are searching for all possible ways to motivate employee's attachment towards their working place (Mitchell, Holtom \& Lee, 2001; Rousseau, 2004). The two specific ways suggested by Rousseau (1998) to strengthen employee's organization commitment are (1) increasing the perception of organizational membership (2) demonstrating the employees that they are valued by organization.

The current human resource practices found that work environment (WE) supervisor support (SS) and training \& development (T\&D) are the variables most relevant to increase commitment towards organization since these factors either demonstrates organizational care and support for employees or creates a sense of belonging and a positive feeling of identification.

This paper tries to fill in the gap in the literature by examining the impact of WE, SS and T\&D, over Organization commitment (OC) among employees of ceramic sanitary ware factories in India, a sector which is unattended, as well as to predict the effects of OC on retention. It also investigates whether organization commitment mediates the effects of above factors on retention. 


\section{Research Motivation}

Ceramic is a diverse industry and contains several categories of products including sanitary ware. The ceramic industry in India came into existence about a century ago and has matured over time to form an industry base. Over the years, the industry has been modernising through new innovations in product profile, quality and design to emerge as a modern world- class industry ready to take global competition. The ceramic products are produced both in organized as well as unorganized sector over the last two decades the technical ceramic segment has recorded an impressive growth. The Indian ceramic industry ranks at $8^{\text {th }}$ position in the world and produce around $2.5 \%$ of global output. The industry provides employment to 5.50 lakhs of people of whom 50,000 are directly employed. During 2008, India was the $24^{\text {th }}$ largest trading nation in the world and Asia pacific holds a significant market share in ceramic sanitary market. Asia -pacific is thus expected to maintain its dominance in the global market owing to the steady growth in China, India and Thailand. The ceramic sanitary ware market estimated to be valued around 4.27 million USD in 2014 is projected to reach 46 billion USD in 2019 (Ceramic industry in India a trade perspective; Ceramic Sanitary Ware Market by Product 2015).

The quarterly survey in Indian manufacturing industries 2014, predicted a strong growth in ceramic sector (over 10\%) in April- June 2014-15 (FICCI, 2014). Also increasing population in the developing nations and increasing standard of living of the people accelerated the growth. Due to this the requirement of work force is increased and on the contrary, India suffers highest turnover rate (26\%) (Hay Group, 2013). Further the "Swach Bharth" scheme of government of India increased the requirements of sanitary ware products, thereby enhancing the need of work force. In addition, anticipated nearly $\$ 1$ trillion of investment in the years to 2018 with half of them expected from private financing, there will be huge demand for labour- totally $14 \%$ of employment in the organized sector-and raising turn over in these activities (Biswas, 2013). Moreover the plight of skilled category of work force in search of greener pastures (Docquier \& Rapoport, 2009) also makes the situation worse and there is an immediate need to ascertain the factors which would prevent the turnover to the maximum extent in the ceramic sanitary ware industries.

\section{Literature Review}

\subsection{Work Environment}

Most of the manufacturing organization felt the need of creating a motivating environment to help employees fully expose their capabilities (Shalley, Gilson \& Blum, 2000). Employees get benefited by work environment that provide sense of belonging (Miller, Erickson \& Yust, 2001) and provision of 
generous personalization policies and sound control on workspace (Wells \& Thelen 2002) enhance the motivation levels of employees to commit with organization for a longer period. Some of the work environment variables, supervisor support, promotion, co-worker relationship, general working conditions (Richards, O’Brien, \& Akroyd, 1994), Social support (Haggins, 2011), perceived organization support (Casper, Martin, Buffardi \& Erdwins, 2002) participation in decision making (Subramaniam \& Mia, 2001) are predictors of organization commitment. The presence of job autonomy (Dunham, Grube \& Castaneda, 1994), positive feedback (Hutchison \& Garstka,1996) also helps to increase commitment of employees. Innovative and supportive organization sub culture (Lok, Westwood \& Crawford, 2005) and ownership of any kind given to employees (Klein, 1987) have strong positive relationship with commitment. The researches (Earle, 2003) identified that requirements of different generations varies and the way they prioritise the value of work environment differs. Hence focus of organization must be on how to provide better working environment so as to maintain better relationship with employees (Levi, 2002). Significant relationship prevails between organization work climate and employees commitment towards organization (Vanaki \& Vagharseyyedin, 2009; Valentine, Godkin \& Lucero, 2002).

Thus organisation which provide employee-friendly work environment crates a good sense of trust among the employees that organisation cares them and this will become a major factor considerably related to their commitment. Hence the hypothesis proposed is:

\section{$H_{1}$ : Work environment will be positively related to $O C$.}

\subsection{Supervisor Support}

The role of supervisor is vital for organization and several studies confirmed that good relationship between supervisor and sub ordinates enhances employee's job-satisfaction (Newsome Jr \& Pillari, 1992), which is considered as a pathway leading to organization commitment (Landsman, 2008). Monitoring workloads and supervisor subordinate relationship by management may not only reduce stress but also increase job satisfaction and commitment to organization (Firth et al., 2004). Trust in supervisor has an important role to play in promoting organization commitment (Perry, 2004). Employees who perceived high support from supervisor expressed stronger feelings of affiliation and loyalty to the organization as perceived support related to supervisor's evaluation, the relationship with supervisor plays important role between employee and organization (Eisenberger, Fasolo, \& Davis-LaMastro, 1990). Supervisor support was found to be an important antecedent of organization commitment (Arzu-Wasti, 2003). Further support from supervisor has a positive effect on organization commitment of employees (Dockel, 2003; Landsman, 2008; Joao, 2010; Heish, 2012). Therefore hypothesis is as follows.

\section{$\mathrm{H}_{2}: \mathrm{SS}$ will be positively related to OC.}




\subsection{Training and Development}

To enhance employees' performance to meet global challenge managerial learning frame work is required (Garg \& Rastogi, 2006). The more knowledge the employee acquire, the more will be their performance. The necessity of increased skills and efficiencies of employees had been felt by organization and they are investing on training programmes. (Huselid, 1995). Provision of training and development opportunities to make employees feel that their organization value them and this increases their attachment towards organization (Dockel, 2003). The researchers Newman, Thanacoody \& Hui (2011) examined the impact of employee's perception of training on organizational commitment and they predicted the importance of training as a tool to enhance the affective commitment of employees.

Skills of workforce is a credential factor for manufacturing industries to compete favourably their business rivals and provision of training and development opportunities are positively related to the commitment of employees towards their organization. (Dockel 2003; Newman et al., 2011; Ahmad \& Bakar, 2003; AlEmadi \& Marquardt, 2007; Bartlett, 2001; Owens, 2006). Therefore the hypothesis is as follows.

$H_{3}:$ T\&D will be positively related to $O C$.

\subsection{Organization Commitment and Retention}

Organization commitment is getting attention due to its ability to produce desirable outcomes for the people and organization (Haldar \& Pareek, 2009). Organization commitment is the most immediate predictor of turnover intention (Igbaria et al., 1994; Parasuraman, 1982) and commitment is negatively related to turnover (Cooper-Hakim \& Viswesvaran, 2005). When organization seek to foster a philosophy of commitment employee's likelihood of seeking other jobs is lowered (Arthur, 1994) and lack of commitment influences intention to quit (Firth et al. 2004). Several studies confirmed that commitment to organization is positively related to retention (Steers, 1977; Jaros,1997; Carmeli \& Weisberg, 2006; Neininger et al. 2010; Firth et al. 2004). The above findings gives evidence that organization commitment is an important factor for employee retention and the hypothesis is as follows.

\section{$\mathrm{H}_{4}: \mathrm{OC}$ will be positively related to retention.}




\subsection{Mediating Role by Organization Commitment}

Simultaneous effects on retention of employees by various factors and OC have been done by many researchers. According to study by Eisenberger et al. (1990), since supervisors are considered to be representatives of organization, perceived supervisor support leads to perceived organization support and able to increase organization commitment and thereby reduce switching over, because individuals tend to respond positively to managements support. Several studies have found that OC mediates the relationship between antecedents of OC with employee retention (Pare \& Tremblay, 2007; Juhdi, Pa'wan \& Hansaram, 2013; SamGnanakkan, 2010). Given that proposed factors are related to OC and OC related to retention, it is possible that OC mediates the relationship between proposed factors and retention. Hence the last hypothesis is as follows.

\section{$H_{5}: O C$ will mediate the relationship between proposed factors and retention.}

\section{Methodology}

\subsection{Sample and Procedures}

The participants of the survey were employees of ceramic sanitary ware factories in India. Given the difficulty to obtain permission to distribute questionnaire from authorities, the researchers managed the distribution to five ceramic sanitary ware factories, located in different places, each of them having more than 150 employees after giving assurance of anonymity. Employees of production, marketing, finance and HR were utilised for this survey.

Each factory was provided 120-130 questionnaire forms with a brief note indicating the purpose of the research. The distribution and collection of forms were conducted by the researchers themselves with the help of few HR department staffs. Totally 550 questionnaire were distributed to employees and 416 usable questionnaire were received back representing a response rate of $75 \%$, the selection of the respondents was based on the simple random sampling. Around $81 \%$ of the respondents were of $25-45$ age group and $73 \%$ of them possess post graduate and professional qualification while $57 \%$ of the respondents falls under 5-15 years of experience. Regarding designation, middle level managers were dominating in the industry and majority of them belong to production department.

Work environment was measured utilizing 4 items adopted from Chew (2004). The example items are "overall this organization is a harmonious place to work" and "workers and management get along in this organization". The reliability coefficient $(\alpha)$ for the items is 0.703 which is above the acceptance level of 0.700 and provides support to the items. 
Supervisor support was measured using 4 questions adopted from Dockel (2003) and the reliability coefficient $(\alpha)$ for the items is 0.713 provides reasonable level of consistency. Example items are "My supervisor looks for opportunities to praise positive employee performance, both privately and in front of others" and "My supervisor often lets me know how well he thinks I am performing job".

Training and Development was measured using 7 items adopted from Dockel (2003) and Chew (2004) the reliability coefficient for the items $(\alpha=0.818)$ gives good level of support to the items. Example items are "I have the opportunity to be involved in activities that promote my professional development" and “people are properly oriented and trained upon joining this organization”.

Organization commitment items were adopted from Mowday, Steers and Porter (1979) that consists of 7 items. The reliability coefficient for the items $(\alpha=0.794)$ gives good level of support to the items. Examples items are "for me this is the best of all possible organizations for which to work" and "I find that my values and the organization's values are very similar".

Finally employee retention was measured using 8 items adopted from Njoroge (2007) and Wang (2012). The reliability coefficient for the items is 0.867 gives good level of support to the items. Examples items are "I like the way my firm does the business and what it stands for" and "Enjoying my job". Respondents were asked to respond the questionnaire on a Likert- scale range from 1- 5, $1=$ strongly disagree and $5=$ strongly agree. Statistical package for the social sciences (SPSS 16.0) has been employed for analysing the data's collected.

All the items were subjected to an assessment of content validity as per the procedure described by Hinkin (1998). A correlation matrix (item by item) of the data was calculated and that matrix was subjected to principle component analysis. A commonly used rule specifies that only variables with loadings greater than 0.40 on a factor should be considered "significant" and used in defining that factor. If nothing beyond this is done, the value of the analysis is limited (Comrey, 1978). The factor loadings of all the items were above 0.40 with no major cross loadings. Further all the items meet Ford, MacCallum and Tait's (1986) heuristic guidelines for meaningful and representative of the construct and examination, and are taken for analysis. 


\section{Results}

Table 1 represents mean, Standard deviation, Cronbach's alpha and correlation matrix of the proposed factors. The alpha co efficient varies from 0.703 to 0.867 concurs with minimum acceptable value of 0.700 (Nunnally \& Bernstein, 1994). There exists correlation among all the variables and ranges from 0.537 to 0.698 . Further all the proposed factors are significantly related to OC and retention.

\begin{tabular}{|l|r|r|r|r|r|r|r|r|}
\hline Proposed Factors & Mean & $\begin{array}{c}\text { Cronbach's } \\
\text { alpha }\end{array}$ & SD & 1 & 2 & 3 & 4 & 5 \\
\hline 1. Work Environment & 17.39 & 0.703 & 1.690 & & & & & \\
\hline 2. Supervisor support & 17.07 & 0.713 & 1.809 & $0.554^{* *}$ & & & & \\
\hline 3. Training \& Development & 25.21 & 0.818 & 2.631 & $0.622^{* *}$ & $0.589^{* *}$ & & & \\
\hline 4. Organization commitment & 30.29 & 0.794 & 2.867 & $0.682^{* *}$ & $0.567^{* *}$ & $0.611^{* *}$ & & \\
\hline 5. Employee retention & 33.50 & 0.867 & 3.550 & $0.573^{* *}$ & $0.698^{* *}$ & $0.537^{* *}$ & $0.614^{* *}$ & 1 \\
\hline
\end{tabular}

$\mathrm{SD}=$ Standard Deviation. ${ }^{* *} p<0.01$

Table 1. Mean, Standard deviation and Cronbach's alpha \& correlation of proposed factors

To determine the relationship between proposed factors and OC, all the factors regressed simultaneously and the results are tabulated in Table 2. As shown in Table 2, the multiple correlation coefficient $(\mathrm{R}=0.738)$ measures the degree of relationship between the actual values and predicted values of organization commitment. Because predicted values are obtained as a linear combination of independent variables, the coefficient value of 0.738 indicated that the relationship between dependent variable and three independent variables is quite strong and positive. The proposed factors exhibits significant amount of variance in OC $\left(\mathrm{R}^{2}=0.541, \mathrm{p}=0.000\right)$. All the three factors are significant predictors of $\mathrm{OC}$ and provides support to the hypothesis $\mathrm{H}_{1}, \mathrm{H}_{2}, \mathrm{H}_{3}$. The strongest predictor is WE (beta $=0.433$ ) and the weakest is SS (beta $=0.193)$.

\begin{tabular}{|l|r|r|r|r|r|r|}
\hline Proposed Factors & p & $\begin{array}{c}\text { Standardized } \\
\text { Beta }\end{array}$ & R & Adjusted R & t & F \\
\hline Work Environment & $0.000^{* *}$ & 0.430 & 0.738 & 0.541 & 9.727 & $163.947 * *$ \\
\hline Supervisor support & $0.000^{* *}$ & 0.193 & & & 4.481 & \\
\hline Training \& Development & $0.000^{* *}$ & 0.229 & & & 4.986 & \\
\hline
\end{tabular}

$* * p<0.01$.

Table 2. Multilinear regression analysis of organization commitment on proposed factors [n $=416]$ 
The regression analysis in Table 3 shows that $O C$ had significant variance $\left(R^{2}=0.375 p=0.000\right)$ in retention and positively related with it, hence provides support to the hypothesis $\mathrm{H}_{4}$.

\begin{tabular}{|l|c|r|r|r|r|r|}
\hline Proposed Factor & $\mathbf{p}$ & $\begin{array}{c}\text { Standardized } \\
\text { Beta }\end{array}$ & R & Adjusted $\mathbf{R}^{2}$ & t & F \\
\hline Organization Commitment & $0.000^{* *}$ & 0.614 & 0.614 & 0.375 & 15.822 & $250.322^{* *}$ \\
\hline$* * p<0.01$ & & &
\end{tabular}

Table 3. Regression Analysis of OC on Employee Retention [ $n=416]$

To determine the relationship between proposed factors and employee retention all the factors regressed simultaneously and the results are tabulated in Table 4. As shown in Table 4, the proposed factors exhibits significant amount of variance in employee retention $\left(\mathrm{R}^{2}=0.538 . \mathrm{p}=0.000\right)$. Of the three factors, WE $(p=0.000)$ and SS $(p=0.000)$ are significant predictors of employee retention. The only insignificant predictor of retention is Training \& Development $(p=0.056)$

\begin{tabular}{|c|c|c|c|c|c|c|c|}
\hline Model No & Proposed Factors & $\mathrm{p}$ & Standardized Beta & $\mathbf{R}$ & Adjusted $\mathbf{R}^{2}$ & t & $\mathrm{F}$ \\
\hline \multirow{3}{*}{ A } & Work Environment & $0.000^{* *}$ & 0.232 & \multirow{3}{*}{0.736} & \multirow{3}{*}{0.538} & 5.197 & \multirow{3}{*}{$162.54^{* *}$} \\
\hline & Supervisor support & $0.000^{* *}$ & 0.518 & & & 11.973 & \\
\hline & Training \& Development & 0.056 & 0.088 & & & 1.916 & \\
\hline \multirow{4}{*}{ B } & Work Environment & $0.008^{* *}$ & 0.129 & \multirow{4}{*}{0.753} & \multirow{4}{*}{0.563} & 2.652 & \multirow{4}{*}{$134.643^{* *}$} \\
\hline & Supervisor support & $0.000^{* *}$ & 0.472 & & & 10.954 & \\
\hline & Training \& Development & 0.464 & 0.034 & & & 0.734 & \\
\hline & Organization Commitment & $0.000^{* *}$ & 0.238 & & & 4.943 & \\
\hline
\end{tabular}

$* * p<0.01$

Table 4. Summary of hierarchical multiple regression analysis of employee retention on proposed factors $[\mathrm{n}=416]$

To determine the mediating effect of OC on the relationship between proposed factors and employee retention, hierarchical regression analysis was performed and displayed in Table 4. According to Baron and Kenny (1986), to establish mediation, the following conditions must hold: 1 . the independent variables (proposed factors) must be related to the mediator (OC) 2. The mediator (OC) must be related to dependent variable (employee retention) 3. Both independent variables (proposed factors) and mediator (OC) must be correlated with dependent variable (employee retention). If the significant relationship between independent variables (proposed variables) and dependent variable is reduced to non-significant after introducing mediator $(\mathrm{OC})$, then it is considered full mediation. However if the 
effect size of the independent variable is reduced after inclusion of mediator then it is considered to be partial mediator. From Table 4 it is found that significant relationship derived for the two factors, WE and SS (model A) is not changed to non-significant but the effect size is reduced (WE $=p=0.008$, beta $=0.129, \mathrm{SS}=\mathrm{p}=0.000$, beta $=0.472)$ after inclusion of mediator variable OC (model B) indicates that OC has partial mediation effects.

Additionally Sobel (1982) tests were carried out to examine the mediating effect of OC on the relationship between the two factors WE and SS with employee retention. The results support the mediation (WE, $Z=7.513, \mathrm{p}<0.01$; SS, $Z=7.031, \mathrm{p}<0.01$ ). To reinforce the evidence of mediating effect of OC, Aroian test (Aroian 1944/47) is also conducted and this also supports the mediation (WE, $Z=7.504, \mathrm{p}<0.01 ; \mathrm{SS}, \mathrm{Z}=7.018, \mathrm{p}<0.01$ ). Hence all the statistical tests supported $\mathrm{OC}$ as partially mediating the relationship between both WE and SS with retention. Further significant effect of OC on employee retention is inferred (beta $=0.238, \mathrm{p}=0.000$ ) and provides partial support to the hypothesis $\mathrm{H}_{5}$.

\section{Discussions}

The purpose of this study was to check the impact of WE, SS and T\&D over OC among employees of ceramic sanitary ware factories in India as well as to verify the effects of OC on retention. Further it also investigates whether organization commitment mediates the effects of above factors on retention.

Employees are influenced by present day's changing environment and this will be have profound impact on the factors influencing OC. The result of the study indicates that proposed factors explained $54.1 \%$ of variance in OC. This signifies that all the proposed factors are influential in enhancing OC, and need to be given top priority. This variance $54.1 \%$ also indicates that OC is very essential as commitment leads to better performance of employees (Siders, George \& Dharwadkar, 2001; Jaramillo, Mulki \& Marshall, 2005; Neininger et al., 2010; Arthur, 1994) and their positive attitudes towards their organization is helpful to achieve the targets.

The findings that indicates WE as the strongest predictor (beta $=0.433$ ) of OC coincide with the earlier findings (Vanaki \& Vagharseyyedin, 2009; Valentine et al., 2002). Employees expect support and encouragement from organization to unfold their potential. Availability of discretion independence, participation in decision making, information sharing, reasonable work tasks, and sufficient work space could be perceived by employee's that organization supports them. More over as indicated by Meyer and Smith (2000), Allen, Shore and Griffeth (2003). They also signal that the organization is supportive of the 
employees and is seeking to establish or maintain a social exchange relationship with them. This highlights the importance of organizational support for work environment to achieve OC.

Support of supervisor also emerged as a predominate factor positively related to OC and concurs with the previous findings (Dockel, 2003; Landsman, 2008; Joao, 2010; Heish, 2012). The support of supervisor effect employee's emotional satisfaction with the job and also contributes to the appraisal of how the organization value them and cares them. Good relationship enhances the job satisfaction and increases organization's care and this will be reciprocated by the employees in the form of OC. Employee expects recognition and appreciation for their good work and when they get it from supervisors, it motivates them to feel that they are component of the organization. Supervisors are considered as "miniorganization" and employee's perception of fair and equitable feedback and support from supervisors provide a chance to make difference in job, exercise discretion and receive feedback on their performance. This increase intrinsic motivation and general job satisfaction (Thomas \& Velthouse, 1990) thereby results in increased attachments towards organization. All these emphasise the importance of organization's support for good relationship between supervisor and subordinates to achieve OC.

The next predominant factor positively related to $\mathrm{OC}$ is $\mathrm{T} \& \mathrm{D}$ which coincides with the researches (Dockel, 2003; Newman et al., 2011; Ahmad \& Bakar, 2003; Al-Emadi \& Marquardt, 2007; Bartlett, 2001; Owens, 2006). Training provisions improves efficiency of employees, of all age groups there by resulting in increased production, consequently workers gets rewards. This will have positive effects towards their organization. When company provides relevant and effective training, employees feel that company is concerned with improving their skill and ability and this will be reflected in their commitment towards organization. As per arguments of Agarwal \& Ferrate (1999) job rotation programmes, mentoring and training conveys to employees that the organization considers human resources to be a competitive advantage and organization is seeking to establish a prolonged relationship with them. Moreover employees, who are aware of the expense of training, might develop a moral obligation to give organization its money's worth, and this will be reciprocated by their commitment towards organization. This highlights the importance of organizational support for training and development to achieve OC. In summary HR managers need to extent their support to the factors WE, SS and T\&D to improve employees commitment towards the organization.

Secondly this analysis provides evidence that OC is positively related to employee's retention and this research result coincides with earlier findings (Steers, 1977; Jaros, 1997; Carmeli \& Weisberg, 2006; Neininger et al., 2010; Firth et al., 2004). This indicates the need to increase employee's OC for successful retention as employees who are less committed may likely to route their commitment in other direction an tend to seek job opportunities elsewhere and this research will provide guidelines to the HR managers struggling in the turn over prone Indian environment. 
Thirdly MLR (Multi Linear Regression) outcomes indicated that WE and SS are significantly related to employee's retention and WE emerged as the strongest predictor coincides with previous findings (Zeytinoglu \& Denton, 2006; Guthrie 2001; Huselid, 1995). The next variable positively related to retention is SS coincides with earlier finding (Dickinson \& Perry, 2002; Smith, 2005; Firth et al., 2004). Able employees, because of their talent presume themselves that they are pivotal for organization and expect more obligations for their continuation. Further a closer look of the demographic profile reveals that most of the participants $(73 \%)$ are possessing higher educational qualifications and this also increases their bargaining capacity. Results indicates that organizations employee friendly work environment and support for good relationship between supervisor -subordinates do satisfy the employees, consequently influences retention, and suggests to HR managers to exercise more importance to above factors. The only variable which is insignificant predictor of retention is T\&D. This result indicates that mere training facilities alone might not help retention. Training increases the skills of employees and employees presume themselves more marketable. More over increased need of workforce and demand for skilled personnel's, makes competitors to offer more benefits to able workers. This tempts trained employees to leave their companies in search of better prospects. This can be minimised by linking training with career benefits and financial rewards and also by offering training involving development of job specific skills.

Finally, OC partially mediates the relationship of both WE and SS with employee retention. In other way, WE and SS are getting indirect effects on retention also through mediator variable, OC.

\section{Implication to Organization}

At the practical level, this research provides some recommendation for HR managers to reduce the likelihood of employees leaving the company. This provides the information about what to do to increase OC which is crucial for better performance and retention. This research indicates that organizational support for WE, SS and T\&D which increases OC is essential. Hence managerial team should extend their support to the above factors in order to generate better understanding and relationship with their employees (Cropanzano \& Mitchell, 2005).

As success or failure of employee's perception of human resource practices depends on the relationship between organization and employees (Kuvaas, 2008), managers need to interact with employees at regular intervals and demonstrate them that organization cares their well-being, besides formulating needed strategy giving importance to the above factors.

Based on the findings which indicated that mere training alone is not sufficient for retention, managers are suggested to include financial and career benefits while offering training to employees. They can 
concentrate on training programmes which develops skills specific to organization (Frazis, Gittleman, Horrigan \& Joyce, 1998) for better results. Involvement of all organizational members and assurance to the employees that there will not be any professional repercussion on the usage of such concessions, and clear communication provides optimal efficiency in retention.

\section{Limitations and Future Research}

Like other studies these analyses also have some limitations. One of the primary limitation of this survey methodology is that the results depends upon the assumption that respondent of the organization know about their organization (Hair, Anderson \& Tatham, 1999). Requirement and demands of employees differ due to their culture, economy and region. This study was conducted in a particular country and also in a particular sector of manufacturing industry and hence results cannot be generalized. One more limitation is that the analysis had been done on the basis of reports given by the respondents, and there is possibility for some bias towards their organization. Future research is suggested incorporating the other variables directly linked to $\mathrm{OC}$, for example variables enhancing the perception of organizational membership like socialization tactics, and emblem of organization may be tried. Further other variables like, job security, succession planning flexible work schedules can also be tried, and the effects of these variables over OC may be compared with this study findings. More specific results can be arrived by conducting researches in other manufacturing industries and also in different countries.

\section{Conclusion}

Although retention of employees has become hot topic in this career turbulent era, practically no empirical research carried out in the fast growing ceramic sector. This research fills the gap in the literature. The findings provide evidence that employee's commitment towards their organization increases their likelihood of continuation in ceramic sanitary ware industries in India. The study also illustrate that work environment and supervisor support and training and development are the influencing determinants highly relevant in predicting employee's organization commitment, in the most turn over prone Indian environment. The result also reveals that organization provisions for training facilities to improve employees skills alone not sufficient enough to retain them and this facilities need to be plugged with promotional and financial benefits. Additionally the result of the study suggests that organization commitment partially mediates the relationship between proposed factors and employee retention. 


\section{References}

Agarwal, R., \& Ferratt, T.W. (1999). Coping with labor scarcity in information technology: Strategies and practices for effective recruitment and retention. Pinnaflex Educational Resources.

Allen, D.G., Shore, L.M., \& Griffeth, R.W. (2003). The role of perceived organizational support and supportive human resource practices in the turnover process. Journal of Management, 29(1), 99-118. http://dx.doi.org/10.1177/014920630302900107

Ahmad, K.Z., \& Bakar, R.A. (2003). The association between training and organizational commitment among white-collar workers in Malaysia. International Journal of Training and Development, 7, 166-185. http://dx.doi.org/10.1111/1468-2419.00179

Al-Emadi, M.A.S., \& Marquardt, M.J. (2007). Relationship between employees' beliefs regarding training benefits and employees' organizational commitment in a petroleum company in the State of Qatar. International Journal of Training and Development, 11(1), 49-70. http://dx.doi.org/10.1111/j.1468-2419.2007.00269.x

Aroian, L.A. (1944/47). The probability function of the product of two normally distributed variables. The Annals of Mathematical Statistics, 18(2), 265-271. http://dx.doi.org/10.1214/aoms/1177730442

Arthur, J.B. (1994). Effects of human resource systems on manufacturing performance and turnover. Academy of Management Journal, 37(3), 670-687. http://dx.doi.org/10.2307/256705

Arzu-Wasti, S. (2003). The influence of cultural values on antecedents of organisational commitment: an individual-level analysis. Applied Psychology, 52(4), 533-554. http://dx.doi.org/10.1111/1464-0597.00150

Bagraim, J. (2010). Multiple affective commitments and salient outcomes: The improbable case of information technology knowledge workers. The Electronic Journal Information Systems Evaluation, 13(2), 97-106.

Baron, R.M., \& Kenny, D.A. (1986). The moderator-mediator variable distinction in social psychological research: Conceptual, strategic, and statistical considerations. Journal of Personality and Social Psychology, 51(6), 1173. http://dx.doi.org/10.1037/0022-3514.51.6.1173

Bartlett, K.R. (2001). The relationship between training and organizational commitment: A study in the health care field. Human Resource Development Quarterly, 12(4), 335-352. http://dx.doi.org/10.1002/hrdq.1001

Beechler, S., \& Woodward, I.C. (2009). The global "war for talent". Journal of International Management, 15(3), 273-285. http://dx.doi.org/10.1016/j.intman.2009.01.002 
Biswas, S. (2013). Attrition in India to top world charts in 2013; one in four employees to change jobs. The Economic Times. Retrieved from: http://articles.economictimes.indiatimes.com/2013-06$\underline{07 / \text { news/3981456 } 1 \text { threeemployees-indian-employees-attrition }}$

Bogdanowicz, M.S., \& Bailey, E.K. (2002). The value of knowledge and the values of the new knowledge worker: generation $X$ in the new economy. Journal of European Industrial Training, 26(2/3/4), 125-129. http://dx.doi.org/10.1108/03090590210422003

Boshoff, C. (2000). The impact of multiple commitments on intentions to resign: An empirical assessment. British Journal of Management, 11(3), 255-272. http://dx.doi.org/10.1111/1467-8551.00165

Carmeli, A., \& Weisberg, J. (2006). Exploring turnover intentions among three professional groups of employees. Human Resource Development International, 9(2), 191-206.

http://dx.doi.org/10.1080/13678860600616305

Casper, W.J., Martin, J.A., Buffardi, L.C., \& Erdwins, C.J. (2002). Work--family conflict, perceived organizational support, and organizational commitment among employed mothers. Journal of occupational bealth psychology, 7(2), 99. http://dx.doi.org/10.1037/1076-8998.7.2.99

Ceramic industry in India a trade perspective [online].

http://newsletters.cii.in/newsletters/mailer/trade talk/pdf/Ceramics\%20Industrv\% $\% 20$ in $\% 20$ India.pdf

Ceramic Sanitary Ware Market by Product (Washbasins, Toilet Sinks, Cisterns, Pedestals and Others), by Technology (Slip Casting, Tape Casting, Pressure Casting, and Isostatic Pressing) and Region-Trends \& Forecasts to 2019. (2015) [online]. http://www.marketsandmarkets.com/Market-Reports/ceramic-sanitary-waremarket-581.html

Chew, J.C.L. (2004). The influence of human resource management practices on the retention of core employees of Australian organisations: An empirical study. Doctoral dissertation. Murdoch University.

Correia de Sousa, M., \& van Dierendonck, D. (2010). Knowledge workers, servant leadership and the search for meaning in knowledge-driven organizations. On the Horizon, 18(3), 230-239. v

Cooper-Hakim, A., \& Viswesvaran, C. (2005). The construct of work commitment: testing an integrative framework. Psychological Bulletin, 131(2), 241. http://dx.doi.org/10.1037/0033-2909.131.2.241

Cropanzano, R., \& Mitchell, M.S. (2005). Social exchange theory: An interdisciplinary review. Journal of management, 31(6), 874-900. http://dx.doi.org/10.1177/0149206305279602

Comrey, A.L. (1978). Common methodological problems in factor analytic studies. Journal of consulting and clinical psychology, 46(4), 648. http://dx.doi.org/10.1037/0022-006X.46.4.648 
Dickinson, N.S., \& Perry, R.E. (2002). Factors influencing the retention of specially educated public child welfare workers. Journal of Health \& Social Policy, 15(3-4), 89-103. http://dx.doi.org/10.1300/J045v15n03_07

Dockel, A. (2003) The effect of retention factors on organizational commitment, an investigation of high technology employees. Masters dissertation. University of Pretoria. Retrieved from: http://repository.up.ac.za/dspace/bitstream/handle/2263/27597/dissertation.pdf?sequence=1\&isAllowed=y

Docquier, F., \& Rapoport, H. (2009). Documenting the brain drain of "la crème de la crème": Three case-studies on international migration at the upper tail of the education distribution. Jabrbücher für Nationalökonomie und Statistik, 229(6), 679-705. http://dx.doi.org/10.1515/jbnst-2009-0603

Dunham, R.B., Grube, J.A., \& Castaneda, M.B. (1994). Organizational commitment: The utility of an integrative definition. Journal of Applied psychology, 79(3), 370. http://dx.doi.org/10.1037/0021-9010.79.3.370

Earle, H.A. (2003). Building a workplace of choice: Using the work environment to attract and retain top talent. Journal of Facilities Management, 2(3), 244-257. http://dx.doi.org/10.1108/14725960410808230

Eisenberger, R., Fasolo, P., \& Davis-LaMastro, V. (1990). Perceived organizational support and employee diligence, commitment, and innovation. Journal of applied psychology, 75(1), 51. http://dx.doi.org/10.1037/00219010.75.1.51

FICCI (2014). Quarterly survey on Indian manufacturing sector, Federation of Indian chambers of commerce and industry manufacturing division. Retrieved from: http://www.FICCI.com./manufacturing-survey-report-2014.pdf

Firth, L., Mellor, D.J., Moore, K.A., \& Loquet, C. (2004). How can managers reduce employee intention to quit? Journal of Managerial Psychology, 19(2), 170-187. http://dx.doi.org/10.1108/02683940410526127

Ford J.K., MacCallum, R.C., \& Tait, M. (1986) The application of exploratory factor analysis in applied psychology: A critical review and analysis. Personnel Psychology, 986, 39. http://dx.doi.org/10.1111/j.17446570.1986.tb00583.x

Frazis, H., Gittleman, M., Horrigan, M., \& Joyce, M. (1998). Results from the 1995 survey of employer-provided training. Monthly Lab. Rev., 121, 3.

Garg, P., \& Rastogi, R. (2006). New model of job design: motivating employees’ performance. Journal of management Development, 25(6), 572-587. http://dx.doi.org/10.1108/02621710610670137

Guthrie, J.P. (2001). High-involvement work practices, turnover, and productivity: Evidence from New Zealand. Academy of Management Journal, 44(1), 180-190. http://dx.doi.org/10.2307/3069345 
Haggins, R. (2011). A correlational study of work environment factors and organizational commitment in southern California staff nurses. Doctoral dissertation. University of Phoenix.

Hair, J., Anderson, R., \& Tatham, R. (1999). William Black. Análisis Multivariante. 5th edition. Madrid, Ed.

Haldar, U.K., \& Pareek, U. (2009). Human Resource Development. Oxford University Press.

Hay Group (2013) 1 in 4 Indian employees set to switch jobs as growth picks up. Retrieved from: http://www.haygroup.com/in/press/details.aspx?id=37383

Heish, H.L. (2012). Building employees' organisational commitment with LMX: the mediating role of supervisor support. Global Journal of Engineering Education, 14(3), 250-255.

Hinkin, T.R. (1998). A brief tutorial on the development of measures for use in survey questionnaires. Organizational Research Methods, 1(1), 104-121. http://dx.doi.org/10.1177/109442819800100106

Huselid, M.A. (1995). The impact of human resource management practices on turnover, productivity, and corporate financial performance. Academy of Management Journal, 38(3), 635-672. http://dx.doi.org/10.2307/256741

Hutchison, S., \& Garstka, M.L. (1996). Sources of Perceived Organizational Support: Goal Setting and Feedback1. Journal of Applied Social Psychology, 26(15), 1351-1366. http://dx.doi.org/10.1111/j.15591816.1996.tb00075.x

Igbaria, M., Meredith, G., \& Smith, D.C. (1994). Predictors of intention of IS professionals to stay with the organization in South Africa. Information \& Management, 26(5), 245-256. http://dx.doi.org/10.1016/03787206(94)90063-9

Ingram, T.N., \& Lee, K.S. (1990). Sales force commitment and turnover. Industrial Marketing Management, 19(2), 149-154. http://dx.doi.org/10.1016/0019-8501(90)90039-X

Jaramillo, F., Mulki, J.P., \& Marshall, G.W. (2005). A meta-analysis of the relationship between organizational commitment and salesperson job performance: 25 years of research. Journal of Business Research, 58(6), 705-714. http://dx.doi.org/10.1016/j.jbusres.2003.10.004

Jaros, S.J. (1997). An assessment of Meyer and Allen's (1991) three-component model of organizational commitment and turnover intentions. Journal of Vocational Behavior, 51(3), 319-337. http://dx.doi.org/10.1006/jvbe.1995.1553

Joao, T.F. (2010). The relationship between perceived career mobility, career mobility preference, job satisfaction and orgarnizational commitment. Master of Arts. Dissertation. University of South Africa. 
Juhdi, N., Pa'wan, F., \& Hansaram, R.M.K. (2013). HR Practices and Turnover intention: The mediating roles of organizational commitment and organizational engagement in a selected region in Malaysia. The International Journal of Human Resource Management, 24(15), 3002-3019.

http://dx.doi.org/10.1080/09585192.2013.763841

Kalliath, T.J., \& Beck, A. (2001). Is the path to burnout and turnover paved by a lack of supervisory support? A structural equations test. New Zealand Journal of Psychology, 30(2), 72-78.

Klein, K.J. (1987). Employee stock ownership and employee attitudes: a test of three models. Journal of Applied Psychology, 72(2), 319. http://dx.doi.org/10.1037/0021-9010.72.2.319

Kramer, M.W., Callister, R.R., \& Turban, D.B. (1995). Information-receiving and information-giving during job transitions. Western Journal of Communication (includes Communication Reports), 59(2), 151-170. http://dx.doi.org/10.1080/10570319509374513

Kuvaas, B. (2008). An exploration of how the employee-organization relationship affects the linkage between perception of developmental human resource practices and employee outcomes. Journal of Management Studies, 45(1), 1-25.

Landsman, M.J. (2008). Pathways to organizational commitment. Administration in Social Work, 32(2), 105-132. http://dx.doi.org/10.1300/J147v32n02_07

Levi, L. (2002). The European Commission's Guidance on work-related stress: from words to action. TUTB Newsletter, 19(20), 12-17.

Lok, P., Westwood, R., \& Crawford, J. (2005). Perceptions of organisational subculture and their significance for organisational commitment. Applied Psychology, 54(4), 490-514.

http://dx.doi.org/10.1111/j.1464-0597.2005.00222.x

Meyer, J.P., \& Smith, C.A. (2000). HRM practices and organizational commitment: Test of a mediation model. Canadian Journal of Administrative Sciences/Revue Canadienne des Sciences de l'Administration, 17(4), 319-331. http://dx.doi.org/10.1111/j.1936-4490.2000.tb00231.x

Meyer, J.P., Stanley, D.J., Herscovitch, L., \& Topolnytsky, L. (2002). Affective, continuance, and normative commitment to the organization: A meta-analysis of antecedents, correlates, and consequences. Journal of Vocational Behavior, 61(1), 20-52. http://dx.doi.org/10.1006/jvbe.2001.1842

Miller, N.G., Erickson, A., \& Yust, B.L. (2001) Sense of place in the workplace: The relationship between personal objects and job satisfaction and motivation. Journal of Interior Design, 27, 35-44. http://dx.doi.org/10.1111/j.1939-1668.2001.tb00364.x 
Mitchell, T.R., Holtom, B.C., \& Lee, T.W. (2001). How to keep your best employees: Developing an effective retention policy. The Academy of Management Executive, 15(4), 96-108.

http://dx.doi.org/10.5465/AME.2001.5897929

Morin, A.J., Morizot, J., Boudrias, J.S., \& Madore, I. (2010). A multifoci person-centered perspective on workplace affective commitment: A latent profile/factor mixture analysis. Organizational Research Methods, 14(1), 58-90. http://dx.doi.org/10.1177/1094428109356476

Mowday, R.T., Steers, R.M., \& Porter, L.W. (1979). The measurement of organizational commitment. Journal of Vocational Behavior, 14(2), 224-247. http://dx.doi.org/10.1016/0001-8791(79)90072-1

Neininger, A., Lehmann-Willenbrock, N., Kauffeld, S., \& Henschel, A. (2010). Effects of team and organizational commitment-A longitudinal study. Journal of Vocational Behavior, 76(3), 567-579. http://dx.doi.org/10.1016/j.jvb.2010.01.009

Newman, A., Thanacoody, R., \& Hui, W. (2011). The impact of employee perceptions of training on organizational commitment and turnover intentions: a study of multinationals in the Chinese service sector. The International Journal of Human Resource Management, 22(8), 1765-1787.

http://dx.doi.org/10.1080/09585192.2011.565667

Newsome Jr., M., \& Pillari, V. (1992). Job satisfaction and the worker-supervisor relationship. The Clinical Supervisor, 9(2), 119-129. http://dx.doi.org/10.1300/J001v09n02_11

Njoroge, S.W. (2007). A survey of factors that influence employee retention in manufacturing firms in Nairobi. Doctoral dissertation. University of Nairobi.

Nunnally, J.C., \& Bernstein, I.H. (1994). Psychometric Theory, (3). New York: McGraw-Hill.

Owens, P.L. (2006). One more reason not to cut your training budget: The relationship between training and organizational outcomes. Public Personnel Management, 35(2), 163-172. http://dx.doi.org/10.1177/009102600603500205

Paillé, P., Fournier, P.S., \& Lamontagne, S. (2011). Relationships between commitments to the organization, the superior and the colleagues, and the intention to leave among truckers. International Journal of Organizational Analysis, 19(2), 92-108. http://dx.doi.org/10.1108/19348831111135056

Parasuraman, S. (1982). Predicting turnover intentions and turnover behavior: A multivariate analysis. Journal of Vocational Behavior, 21(1), 111-121. http://dx.doi.org/10.1016/0001-8791(82)90056-2 
Paré, G., \& Tremblay, M. (2007). The influence of high-involvement human resources practices, procedural justice, organizational commitment, and citizenship behaviors on information technology professionals' turnover intentions. Group \& Organization Management, 32(3), 326-357. http://dx.doi.org/10.1177/1059601106286875

Perry, R.W. (2004). The relationship of affective organizational commitment with supervisory trust. Review of Public Personnel Administration, 24(2), 133-149. http://dx.doi.org/10.1177/0734371X03262452

Richards, B., O’Brien, T., \& Akroyd, D. (1994). Predicting the organizational commitment of marketing education and health occupations education teachers by work related rewards. Journal of Industrial Teacher Education, 32(1), 49-64.

Rousseau, D.M. (1998). Why workers still identify with organizations. Journal of Organizational Behavior, 19(3), 217-233. http://dx.doi.org/10.1002/(SICI)1099-1379(199805)19:3<217::AID-JOB931>3.0.CO;2-N

Rousseau, D.M. (2004). Psychological contracts in the workplace: Understanding the ties that motivate. The Academy of Management Executive, 18(1), 120-127. http://dx.doi.org/10.5465/AME.2004.12689213

Saks, A.M. (1996). The Relationship Between the Amount and Helpfulness of Entry Thaining and Work Outcomes. Human Relations, 49(4), 429-451. http://dx.doi.org/10.1177/001872679604900402

SamGnanakkan, S. (2010). Mediating role of organizational commitment on HR practices and turnover intention among ICT professionals. Journal of Management Research, 10(1), 39.

Shalley, C.E., Gilson, L.L., \& Blum, T.C. (2000). Matching creativity requirements and the work environment: Effects on satisfaction and intentions to leave. Academy of Management Journal, 43(2), 215-223. http://dx.doi.org/10.2307/1556378

Siders, M.A., George, G., \& Dharwadkar, R. (2001). The relationship of internal and external commitment foci to objective job performance measures. Academy of Management Journal, 44(3), 570-579. http://dx.doi.org/10.2307/3069371

Sinha, M. (2013) India in the eye of an employee turnover storm business line. http://www.thehindubusinessline.com/economy/india-in-the-eye-of-an-employee-turnover-storm-survey/article4791185.ece

Smith, B.D. (2005). Job retention in child welfare: Effects of perceived organizational support, supervisor support, and intrinsic job value. Children and Youth Services Review, 27(2), 153-169. http://dx.doi.org/10.1016/j.childyouth.2004.08.013

Sobel, M.E. (1982). Asymptotic confidence intervals for indirect effects in structural equation models. Sociological Methodology, 13(1982), 290-312. http://dx.doi.org/10.2307/270723 
Somers, M.J. (1995). Organizational commitment, turnover and absenteeism: An examination of direct and interaction effects. Joumal of Organizational Behavior, 16(1), 49-58. http://dx.doi.org/10.1002/job.4030160107

Steers, R.M. (1977). Antecedents and outcomes of organizational commitment. Administrative Science Quarterly, 22(1) 46-56. http://dx.doi.org/10.2307/2391745

Subramaniam, N., \& Mia, L. (2001). The relation between decentralised structure, budgetary participation and organisational commitment: the moderating role of managers' value orientation towards innovation. Accounting, Auditing \& Accountability Journal, 14(1), 12-30. http://dx.doi.org/10.1108/09513570110381051

Thomas, K.W., \& Velthouse, B.A. (1990). Cognitive elements of empowerment: An "interpretive" model of intrinsic task motivation. Academy of Management Review, 15(4), 666-681.

Valentine, S., Godkin, L., \& Lucero, M. (2002). Ethical context, organizational commitment, and personorganization fit. Journal of Business Ethics, 41(4), 349-360. http://dx.doi.org/10.1023/A:1021203017316

Vanaki, Z., \& Vagharseyyedin, S.A. (2009). Organizational commitment, work environment conditions, and life satisfaction among Iranian nurses. Nursing \& Health Sciences, 11(4), 404-409. http://dx.doi.org/10.1111/j.1442-2018.2009.00473.x

Wang, Y.H. (2012). Recruitment and retention of knowledge workers in Taiwan's high technology industry. Doctoral dissertation. Cardiff University).

Wells, M., \& Thelen, L. (2002). What does your workspace say about you? The influence of personality, status, and workspace on personalization. Environment and Behavior, 34(3), 300-321. http://dx.doi.org/10.1177/0013916502034003002

Zeytinoglu, I.U., \& Denton, M. (2006). Satisfied workers, retained workers: Effects of work and work environment on homecare workers' job satisfaction, stress, physical health, and retention (p. 117). Research Institute for Quantitative Studies in Economics and Population. McMaster University.

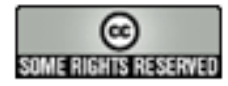

Article's contents are provided on an Attribution-Non Commercial 3.0 Creative commons license. Readers are allowed to copy, distribute and communicate article's contents, provided the author's and Journal of Industrial Engineering and Management's names are included. It must not be used for commercial purposes. To see the complete license contents, please visit http://creativecommons.org/licenses/by-nc/3.0/. 